\title{
Nutritive and Mineral Composition in a Collection of Cucurbita pepo L Grown in Kosova
}

\author{
Sali Aliu*, Imer Rusinovci, Shukri Fetahu, Salih Salihu, Refki Zogaj \\ Faculty of Agriculture and Veterinary, Department of Crop Science, University of Prishtina, Prishtina, Kosova. \\ Email: salialiu02@gmail.com, sali.aliu@uni-pr.edu
}

Received November 21 ${ }^{\text {st }}, 2011$; revised March $14^{\text {th }}, 2012$; accepted March 22 $2^{\text {nd }}, 2012$

\begin{abstract}
In Kosovo, in most cases C. pepo is grown both in maize fields and vegetable gardens as well as in other more intensive systems. Our expedition has identified different location $t$ of Kosovo where we were collected a samples at altitudes from 545 till 748 m.a.s.l. The aim of the present investigation was carried out to study morphological diversity, protein and lipids content. Protein content (PC) was determined by Kjeldahl method. Lipids were determined by extraction using Soxhlet apparatus and diethyl ether was used as extraction solvent. Pumpkin populations show great diversity for quality traits. The greater part of variance was accounted for Protein Content (PC) and Lipid Content (LC). The estimation overall value $\mu$ in seed for PC and LC were $14.59 \%$, and $32.99 \%$ respectively. The genetic diversity studies of the investigated of $C$. pepo showed significant genetic variation on chemical parameters, which could be largely due to that they were of different origins. This evaluation of traits variability can assist breeders to identify populations with desirable characteristics for inclusion in variety breeding programs.
\end{abstract}

Keywords: Pumpkin; Diversity; Protein Content; Lipid Content; Mineral Elements

\section{Introduction}

One plant group with the most species used as human food is the Cucurbitaceae family. Within this family, the genus Cucurbita stands out as one of the most important. The Cucurbitaceae family consists of 90 genera and approximately 700 species [1]. Nowadays C. pepo are grown all over the world. Cucurbits are among the most important plant families supplying with edible products and useful fibers [2]. Kosovo is one of the important diversity centers for $C$. pepo because of their adaptation to diverse agro ecological conditions as a result of natural and also farmer's selection. In Kosovo, in most cases $C$. pepo is grown both in maize fields and vegetable gardens as well as in other more intensive agricultural systems. Like the other cultivated species of the genus, the mature or young fruit and the seeds of C. pepo, as well as to a lesser extent the flowers and young tips of the stems are eaten in many parts of its native distribution area and in other regions of the world. C. pepo's nutrient content is similar to that described for the other cultivated species [3]. Pumpkin (C. pepo) sees are a moderate to very good source of a variety of nutrients, including minerals, protein and healthy fats. They provide a significant of dietary copper, zinc, iron and magnesium. Traditionally in

\footnotetext{
*Corresponding author.
}

our country, pumpkin is mostly used and cultivated when mature for human food, baking including the fruit flesh which together with cereals paste mixes and prepared food called pie. Also, the seeds are used in nutrition in various forms and the seeds may be eaten whole. Curcurbit seeds are good sources of lipids and proteins [4]. Seeds oil pumpkins are a good row material for the production of oil used in food preparation and in medicine [5].The C. pepo has long been cultivated not only for food but also for their medicinal properties. Particular medicinal properties have been attributed to each part of the fruit and the plant. Pumpkin seed help stimulate appetite, are beneficial for the teeth, nerves, hair and nails. Today, C. pepo is among the economically most important vegetable crops worldwide and is grown in almost all temperate and subtropical regions [6]. The traditional landraces are the important genetic resources for plant breeders because of their considerable genotypic variations. Evaluation of the primitive cultivars and their germplasm are used to develop new cultivars with more productivity and nutritive value. A wider genetic base of C. pepo, thus, assumes priority in plant breeding research developing new varieties for increased agronomical traits such as productivity and nutritive value. The objective of this study is to evaluate the collection of pumpkin populations from different geographical zones in Kosovo. C. 
pepo for mineral composition and nutritive value.

\section{Materials and Methods}

\subsection{Plant Material and Collection Sites}

The field survey was carried out during year 2010 with aim of determining and preserving the characteristics of pumpkin populations (PP). Pumpkin populations used in this study were collected from different regions in Kosova and variation in mineral contents and nutritive values including protein and lipids content was assessed. The accession number and geographical distribution of Pumpkin populations was given Table 1. In total, 12 populations were investigated.

\subsection{Proteins and Lipids Extraction}

At harvest time, the pumpkin fruits were taken to the Faculty of Agriculture in Prishtina, which were analyzed for protein and lipids content were determined at department of Chemistry. The protein content (PC) was determined by the Kjeldahl method, while lipd content (LC) was determined by extraction using Soxhlet apparatus and diethyl ether was used as extraction solvent. Mineral elements include $\mathrm{Fe}, \mathrm{Ca}, \mathrm{Zn}, \mathrm{Mg}$ and $\mathrm{Na}, \mathrm{K}, \mathrm{Cu}$ in ppm per populations is determined through burning and mineralize sample at $550^{\circ} \mathrm{C}$ at $4-6$ hours and then digested sample we set in $\mathrm{HCl}$ (ratio 1:4).

\subsection{Statistical Analyses}

Duncan's multiple range test was used to compare means and significance was accepted at LSD $p=0.05$ level of

Table 1. Accessions of Cucurbita pepo and their geographical origin.

\begin{tabular}{ccccc}
\hline Code & Longitude & Latitude & Elevation & Geographical origin \\
\hline FAPP-01 & $020^{\circ} 56^{\prime} 54^{\prime \prime}$ & $42^{\circ} 50^{\prime} 46^{\prime \prime}$ & 529 & Vushtrri \\
FAPP-02 & $021^{\circ} 06^{\prime} 26^{\prime \prime}$ & $42^{\circ} 50^{\prime} 46^{\prime \prime}$ & 545 & Ferizaj \\
FAPP-03 & $021^{\circ} 13^{\prime} 56^{\prime \prime}$ & $42^{\circ} 20^{\prime} 35^{\prime \prime}$ & 562 & Ferizaj \\
FAPP-04 & $021^{\circ} 11^{\prime} 08^{\prime \prime}$ & $42^{\circ} 41^{\prime} 48^{\prime \prime}$ & 621 & Prishtinë \\
FAPP-05 & $021^{\circ} 07^{\prime} 10^{\prime \prime}$ & $43^{\circ} 00^{\prime} 17^{\prime \prime}$ & 748 & Podujevë \\
FAPP-06 & $021^{\circ} 07^{\prime} 10^{\prime \prime}$ & $43^{\circ} 00^{\prime} 17^{\prime \prime}$ & 748 & Podujevë \\
FAPP-07 & $021^{\circ} 19^{\prime} 75^{\prime \prime}$ & $42^{\circ} 38^{\prime} 57^{\prime \prime}$ & 601 & Drenas \\
FAPP-08 & $021^{\circ} 09^{\prime} 70^{\prime \prime}$ & $42^{\circ} 26^{\prime} 46^{\prime \prime}$ & 613 & Ferizaj \\
FAPP-09 & $021^{\circ} 06^{\prime} 30^{\prime \prime}$ & $42^{\circ} 22^{\prime} 54^{\prime \prime}$ & 610 & Ferizaj \\
FAPP-10 & $021^{\circ} 18^{\prime} 74^{\prime \prime}$ & $42^{\circ} 07^{\prime} 90^{\prime \prime}$ & 594 & Fushë Kosovë \\
FAPP-11 & $021^{\circ} 00^{\prime} 63^{\prime \prime}$ & $42^{\circ} 38^{\prime} 50^{\prime \prime}$ & 587 & Fushë Kosovë \\
FAPP-12 & $021^{\circ} 06^{\prime} 30^{\prime \prime}$ & $42^{\circ} 22^{\prime} 54^{\prime \prime}$ & 613 & Ferizaj \\
\hline
\end{tabular}

significance, to performed for each trait and to identify the variability within populations. Mean values of the agronomic traits for pumpkin populations were standardized and used for computing Euclidean distances between them. Statistical analysis was performed using the statistical program of MINITAB-14, SASS-JMP-IN 5.1.2 (2004) and Excel program.

\section{Results and Discussion}

The present collection showed appreciable genotypic variation for qualitative trats. C. pepo is perhaps the most variable species for variation characteristics in the plant kingdom. The results were obtained in our study demonstrated that substantial differences in qualitative parameters (proteins and lipids) exist in pumpkin populations. The 12 pumpkin populations studied had considerable variation in proteins and lipids. The seed protein content ranged from $9.53 \%$ to $19.73 \%$. The average values of proteins level in fruit flesh (PFF) and fruit skin (PFS) were $1.35 \%$ and $8.03 \%$. The seed protein content $(14.59 \%)$ was significantly higher than FT and FS protein content (Table 2). The protein content of C. pepo was also assayed by Logan [7] to be $18.9 \%$, [4] 32.03\%.

The pumpkin seed oil (lipids) typically is highly unsaturated oil. The variability in the lipid content is very high resulting from a broad genetic diversity. The results of the study show that these seeds contain good amounts of oil that can be exploited. Significant variability was observed among the 12 pumpkin populations for seed lipid (SL) content and it was ranged from $37.46 \%$ to $23.56 \%$. Overall mean of SL were $32.99 \%$. [8] showed that $C$. pepo seeds (CPS) are rich in oil and they contain about $50 \%$ oil. The lipid content in fruit flesh (LCFF) range from $2.81 \%$ to $1.41 \%$. The lipid content of fruit skin (LCFS) studied are significantly higher, which ranged from $2.06 \%$ to $1.51 \%$ (Table 3). Many authors [9] present results for oil content from $37 \%$ to $51 \%$. Also the lipid content was also assayed by Achu [4]) which present results from $41.90 \%$ to $53.85 \%$, and compared our results we have a decrease of lipid content. Results are present in Table 2.

More than one-third of the world's population is afflicted by iron $(\mathrm{Fe})$ and zinc $(\mathrm{Zn})$ deficiencies, these ranking fifth and sixth among the ten most important risk causes of illness and disease in low-income countries [10]. Quantities of minerals in cultivated plants are influenced by numerous complex factors including genotype, soil, environmental conditions and nutrition interactions [11]. Iron (Fe), zinc ( $\mathrm{Zn})$ are essential micronutrient for humans. The obtained results of $\mathrm{Fe}$ and $\mathrm{Zn}$ showed that had higher variation between studied genotypes. Overall average value for Fe was 2.87 ppm respectively for $\mathrm{Zn} 1.32 \mathrm{ppm}$. Calcium (Ca) plays a major role 
Table 2. Protein and lipid content of $C$. pepo populations (\%).

\begin{tabular}{|c|c|c|c|c|c|c|}
\hline \multirow{2}{*}{ Accessions } & \multicolumn{3}{|c|}{ Proteins } & \multicolumn{3}{|c|}{ Lipids } \\
\hline & Seed & Fruit flesh & Fruit skin & Seed lipids & Fruit Flesh & Fruit skin \\
\hline FAPP-01 & $19.26^{\mathrm{ab}}$ & $1.21^{\mathrm{cde}}$ & $8.26^{\mathrm{abcd}}$ & $37.46^{\mathrm{a}}$ & $2.81^{\mathrm{a}}$ & $2.06^{\mathrm{a}}$ \\
\hline FAPP-02 & $18.53^{\mathrm{bc}}$ & $1.26^{\mathrm{cde}}$ & $8.83^{\mathrm{a}}$ & $35.71^{\mathrm{b}}$ & $2.81^{\mathrm{a}}$ & $1.86^{\mathrm{abc}}$ \\
\hline FAPP-03 & $19.73^{\mathrm{a}}$ & $0.93^{\mathrm{e}}$ & $7.96^{\mathrm{cd}}$ & $36.53^{\mathrm{ab}}$ & $2.41^{\mathrm{a}}$ & $1.91^{\mathrm{ab}}$ \\
\hline FAPP-04 & $18.11^{\mathrm{c}}$ & $1.03^{\mathrm{de}}$ & $7.91^{\mathrm{cd}}$ & $35.93^{\mathrm{ab}}$ & $2.53^{\mathrm{a}}$ & $2.06^{\mathrm{a}}$ \\
\hline FAPP-05 & $18.03^{\mathrm{c}}$ & $0.93^{\mathrm{e}}$ & $8.01^{\mathrm{cd}}$ & $37.16^{\mathrm{ab}}$ & $2.46^{\mathrm{a}}$ & $1.51^{\mathrm{c}}$ \\
\hline FAPP-06 & $19.16^{\mathrm{ab}}$ & $0.92^{\mathrm{e}}$ & $7.73^{\mathrm{d}}$ & $37.31^{\mathrm{ab}}$ & $2.36^{\mathrm{a}}$ & $1.81^{\mathrm{abc}}$ \\
\hline FAPP-07 & $10.16^{\mathrm{de}}$ & $1.66^{\mathrm{b}}$ & $8.13^{\mathrm{bcd}}$ & $23.56^{\mathrm{f}}$ & $1.51^{\mathrm{b}}$ & $1.73^{\mathrm{abc}}$ \\
\hline FAPP-08 & $10.51^{\mathrm{de}}$ & $1.46^{\mathrm{bc}}$ & $8.63^{\mathrm{ab}}$ & $30.36^{\mathrm{d}}$ & $1.71^{\mathrm{b}}$ & $1.93^{\mathrm{ab}}$ \\
\hline FAPP-09 & $10.66^{\mathrm{d}}$ & $2.23^{\mathrm{a}}$ & $8.06^{\text {bcd }}$ & $31.16^{\mathrm{d}}$ & $1.66^{\mathrm{b}}$ & $1.63^{\mathrm{bc}}$ \\
\hline FAPP-10 & $9.53^{\mathrm{e}}$ & $1.36^{\mathrm{bcd}}$ & $6.43^{\mathrm{e}}$ & $26.53^{\mathrm{e}}$ & $1.63^{\mathrm{b}}$ & $1.81^{\mathrm{abc}}$ \\
\hline FAPP-11 & $10.56^{\mathrm{d}}$ & $1.73^{\mathrm{b}}$ & $8.13^{\text {bcd }}$ & $31.21^{\mathrm{cd}}$ & $1.36^{\mathrm{b}}$ & $1.71^{\mathrm{abc}}$ \\
\hline FAPP-12 & $10.91^{\mathrm{d}}$ & $1.51^{\mathrm{bc}}$ & $8.36^{\mathrm{abc}}$ & $33.01^{\mathrm{c}}$ & $1.41^{\mathrm{b}}$ & $1.93^{\mathrm{ab}}$ \\
\hline Mean & 14.59 & 1.35 & 8.03 & 32.99 & 2.05 & 1.83 \\
\hline
\end{tabular}

*Means in each column followed by the same letter are not significantly different at the 0.05 probability level.

Table 3. Average values for mineral contents at Cucurbita pepo $\mathrm{L}$ in $\mathrm{ppm}$.

\begin{tabular}{|c|c|c|c|c|c|c|c|}
\hline Accessions & $\mathrm{Cu}$ & $\mathrm{Mg}$ & $\mathrm{Zn}$ & $\mathrm{Fe}$ & $\mathrm{Na}$ & K & $\mathrm{Ca}$ \\
\hline FAPP-01 & $0.56^{\mathrm{h}}$ & $3.51^{\mathrm{h}}$ & $1.79^{\mathrm{c}}$ & $2.83^{\mathrm{f}}$ & $1.31^{\mathrm{g}}$ & $9.95^{\mathrm{a}}$ & $24.13^{\mathrm{e}}$ \\
\hline FAPP-02 & $0.83^{\mathrm{e}}$ & $3.58^{\mathrm{g}}$ & $2.15^{\mathrm{a}}$ & $4.51^{\mathrm{b}}$ & $1.86^{\mathrm{f}}$ & $9.56^{\mathrm{b}}$ & $24.67^{\mathrm{c}}$ \\
\hline FAPP-03 & $0.69^{\mathrm{f}}$ & $3.48^{\mathrm{i}}$ & $0.67^{\mathrm{k}}$ & $2.22^{\mathrm{h}}$ & $1.03^{\mathrm{h}}$ & $5.95^{\mathrm{f}}$ & $22.60^{\mathrm{i}}$ \\
\hline FAPP-04 & $0.56^{\mathrm{h}}$ & $3.46^{\mathrm{j}}$ & $0.83^{\mathrm{j}}$ & $1.74^{\mathrm{k}}$ & $1.96^{\mathrm{e}}$ & $2.34^{\mathrm{k}}$ & $23.33^{\mathrm{h}}$ \\
\hline FAPP-05 & $0.63^{\mathrm{g}}$ & $3.25^{\mathrm{h}}$ & $1.62^{\mathrm{e}}$ & $5.02^{\mathrm{a}}$ & $1.02^{\mathrm{h}}$ & $9.35^{\mathrm{c}}$ & $23.87^{\mathrm{g}}$ \\
\hline FAPP-06 & $0.97^{\mathrm{d}}$ & $3.22^{\mathrm{k}}$ & $0.86^{\mathrm{i}}$ & $3.13^{\mathrm{d}}$ & $0.63^{\mathrm{j}}$ & $9.26^{\mathrm{d}}$ & $25.61^{\mathrm{b}}$ \\
\hline FAPP-07 & $0.56^{\mathrm{h}}$ & $3.65^{\mathrm{f}}$ & $0.90^{\mathrm{h}}$ & $2.29^{\mathrm{g}}$ & $0.91^{\mathrm{i}}$ & $5.11^{\mathrm{g}}$ & $26.01^{\mathrm{a}}$ \\
\hline FAPP-08 & $0.83^{\mathrm{e}}$ & $3.67^{\mathrm{e}}$ & $1.93^{\mathrm{b}}$ & $3.82^{\mathrm{c}}$ & $0.35^{\mathrm{k}}$ & $4.88^{\mathrm{h}}$ & $24.02^{\mathrm{f}}$ \\
\hline FAPP-09 & $1.90^{\mathrm{c}}$ & $4.52^{\mathrm{d}}$ & $1.44^{\mathrm{f}}$ & $2.51^{\mathrm{g}}$ & $2.33^{\mathrm{d}}$ & $8.67^{\mathrm{e}}$ & $24.11^{\mathrm{e}}$ \\
\hline FAPP-10 & $2.01^{\mathrm{b}}$ & $6.61^{\mathrm{a}}$ & $1.14^{\mathrm{g}}$ & $2.01^{\mathrm{j}}$ & $3.33^{\mathrm{b}}$ & $4.01^{\mathrm{j}}$ & $24.41^{\mathrm{d}}$ \\
\hline FAPP-11 & $0.80^{\mathrm{e}}$ & $5.01^{\mathrm{b}}$ & $1.72^{\mathrm{d}}$ & $3.01^{\mathrm{e}}$ & $4.67^{\mathrm{a}}$ & $4.67^{\mathrm{i}}$ & $19.87^{\mathrm{j}}$ \\
\hline FAPP-12 & $3.50^{\mathrm{a}}$ & $4.61^{\mathrm{c}}$ & $0.91^{\mathrm{h}}$ & $1.33^{1}$ & $3.22^{\mathrm{c}}$ & $8.67^{\mathrm{e}}$ & $23.33^{\mathrm{h}}$ \\
\hline Mean & 1.17 & 4.02 & 1.32 & 2.87 & 1.89 & 6.86 & 23.82 \\
\hline
\end{tabular}

*Means in each column followed by the same letter are not significantly different at the 0.05 probability level.

in plant growth and development and in the maintenance and modulation of various cell function, especially related to membrane structure and function and to cell wall structure [12]. At last 22 mineral elements are required for the well-being of humans and these can be supplied by a balanced diet [13]. The results revealed that the $\mathrm{Ca}$ concentration on seed C. pepo were significantly higher on $p=0.01$ respectively (Table 3 ). Overall mean was $23.82 \mathrm{ppm}$, while genetic variation between genotypes for $\mathrm{Ca}$ was $+6.18 \mathrm{ppm}$ or expressed in relative value was 25.94\%. Also, the content of Magnesium (Mg), Phosphorus (P), Natrium (Na) and Kalium (K) was very in- 
Table 4. Correlations matrix between the seventeen variables measured in potato genotypes.

\begin{tabular}{|c|c|c|c|c|c|c|c|c|c|c|c|c|c|}
\hline Trait & SP & PFF & PFS & SL & LCFF & LCFS & $\mathrm{Cu}$ & $\mathrm{Mg}$ & $\mathrm{Zn}$ & $\mathrm{Fe}$ & $\mathrm{Na}$ & $\mathrm{K}$ & $\mathrm{Ca}$ \\
\hline SP & 1 & & & & & & & & & & & & \\
\hline PFF & -0.78 & 1 & & & & & & & & & & & \\
\hline PFS & 0.19 & 0.12 & 1 & & & & & & & & & & \\
\hline SL & $0.87^{* *}$ & $-0.63^{* *}$ & $0.30^{*}$ & 1 & & & & & & & & & \\
\hline LCFF & $0.94^{* *}$ & $-0.70^{* *}$ & 0.20 & $0.78^{* *}$ & 1 & & & & & & & & \\
\hline LCFS & 0.28 & -0.31 & 0.14 & 0.25 & 0.32 & 1 & & & & & & & \\
\hline $\mathrm{Cu}$ & -0.50 & $0.38^{*}$ & -0.19 & -0.22 & -0.53 & -0.01 & 1 & & & & & & \\
\hline $\mathrm{Mg}$ & $-0.69^{* *}$ & $0.46^{*}$ & $-0.65^{* *}$ & $-0.58^{* *}$ & -0.62 & -0.14 & $0.57^{* *}$ & 1 & & & & & \\
\hline $\mathrm{Zn}$ & -0.04 & 0.22 & $0.46^{*}$ & 0.10 & 0.17 & -0.14 & -0.23 & -0.03 & 1 & & & & \\
\hline $\mathrm{Fe}$ & 0.32 & -0.23 & $0.38^{*}$ & $0.32^{*}$ & 0.41 & $-0.44^{*}$ & $-0.49^{*}$ & -0.40 & $0.73^{* *}$ & 1 & & & \\
\hline $\mathrm{Na}$ & -0.47 & $0.45^{*}$ & -0.27 & -0.24 & -0.49 & -0.10 & $0.49^{*}$ & $0.76^{* *}$ & 0.06 & $-0.36^{*}$ & 1 & & \\
\hline $\mathrm{K}$ & $0.38^{*}$ & -0.06 & 0.37 & $0.50^{* *}$ & 0.38 & -0.22 & 0.17 & -0.34 & 0.33 & $0.43^{*}$ & -0.23 & 1 & \\
\hline $\mathrm{Ca}$ & 0.11 & -0.13 & -0.08 & -0.16 & 0.23 & 0.002 & -0.02 & -0.26 & -0.14 & 0.10 & $-0.66^{* *}$ & 0.29 & 1 \\
\hline
\end{tabular}

*The same letters are not significantly different at the 0.05 probability level.

teresting. The content was different between genotypes. Results are presented in Table 3.

From the correlative analysis of traits according to Pearson, are ascertained variable values of the phenotypic correlation coefficient. We observed a high positive correlations $\left(\mathrm{r}=0.94^{* * *}\right)$ between Seed Protein (SP) and Lipid content in fruit flesh (LCFF). There were significant correlation $\left(\mathrm{r}=0.87^{* *}\right)$ between Seed protein (SP) and Seed lipid (SL). The some positive correlation was also observed SL and LCFF on correlation value $r=$ $0.78^{* *}$. Results are presented in Table 4.

\section{Conclusion}

This study has presented a better knowledge of the $C$. pepo populations collected from different regions of Kosova. Mineral content and qualitative characterization showed significant differences between populations which exhibited higher protein and lipids content in seed and different parts of fruit. C. pepo populations also had a significant correlation between studied parameters which had an important role in plant genetic resources. These populations are an important source of diversity which could be used in future in different kind processing industry.

\section{REFERENCES}

[1] G. Francois, B. Nathalie, V. J. Pierre, P. Daniel and M. Didier, "Effect of Roasting on Tocopherols of Gourd Seeds (Cucurbita pepo)," Grasas y aceites, Vol. 57, No. 4,
2006, pp. 409-414.

[2] D. Bisognin, "Origin and Evaluation of Cultivated $\mathrm{Cu}-$ curbits," Ciencia Rural, Vol. 32, No. 4, 2002, pp. 859865. doi:10.1590/S0103-84782002000400028

[3] J. E. H. Bermejo and J. León, "Neglected Crops: 1492 from a Different Perspective," Plant Production and Protection Series No. 26, FAO, Rome, 1994, pp. 63-77.

[4] M. Achi, E. Fokou, C. Tchiegang, M. Fotso and F. Mbiapo, "Nutritive Value of Some Cucurbutaceae Oilseeds from Different Regions in Cameroon," African Journal of Biotechnology, Vol. 4, No. 11, 2005, pp. 1334-1339.

[5] S. Lazos, "Nutritional, Fatty Acids and Oil Characteristics of Pumpkin and Melon Seeds," Journal of Food Science, Vol. 15, 1986, pp. 1382-1383.

[6] H. Paris, "Summer Squash; History, Diversity and Distribution," Horticultural Technologies, Vol. 6, 1996, pp. 6-13.

[7] B. Logan, B. Adams, W. Adams and S. Grace, "Antioxidants and Xantophyll Cycle-Dependent Energy Dissipation in Cucurbita pepo L and Vinca Major L. Acclimated to Four Growth PPFDs in the Field," Journal of Experimental Botany, Vol. 49, No. 328, 1998, pp. 1869-1879. doi:10.1093/jexbot/49.328.1869

[8] Y. M. Yonis, S. Ghirmay and S. Al-Shihry, "African Cucurbita pepo L, Properties of Seed and Variability in Fatty Acid Composition of Seed Oil," Phytochemistry, Vol. 54, No. 1, 2000, pp. 71-75. doi:10.1016/S0031-9422(99)00610-X

[9] D. Stivenson, F. Eller, L. Wang, J. Jane, T. Wang and G. Inglett, "Oil and Tocopherol Content and Composition of Pumpkin Seed Oil in 12 Cultivars," Journal of Agricultural and Food Chemistry, Vol. 55, No. 10, 2007, pp. 4005-4013. doi:10.1021/if0706979 
[10] World Health Organization (WHO), "The World Health Report," Geneva, 2002.

[11] D. Šimič, R. Sudar, T. Ledencan, A. Jamnrovic, Z. Zdunic, I. Brkic and V. Kovacevic, "Genetic Variation of Bioavailable Iron and Zinc in Grain of a Maize Population," Journal of Cereal Science, Vol. 50, No. 3, 2009, pp. 392-397. doi:10.1016/j.jcs.2009.06.014

[12] J. Palta, "Improving Potato Tuber Quality and Production by Targeted Calcium Nutrition," Potato Research, Vol. 53, No. 4, 2010, pp. 267-275. doi:10.1007/s11540-010-9163-0

[13] K. Subramanian, G. Ramsay, C. White, A. Hackett and M. Broadley, "Exploiting Genetic Variation for Elevated Minerals Concentrations in Potatoes," EUCARPIA, Wageningen, 27-30 June 2010, pp. 89-92. 